The organization being developed by the British gas industry in order to provide such a service is described. It is emphasized that while large firms can burn coal efficiently themselves or use it in producers, and can employ technologists of their own, small firms must depend entirely on outside specialized services. Hence although large firms use more gas, the supplying of small firms is of particular value to the gas industry.

\section{Energy Supply for Electric Railways}

ANoтнer paper read at the Vienna Sectional Meeting of the World Power Conference, by Mr. F. Lydall, a member of the well-known firm of Merz and McLellan, consulting engineers, discusses the. requirements and the supply of energy for electric railways. It is divided into four sections. The first discusses the energy requirements for electric traction. Mr. Lydall shows that these are much smaller than usually estimated. As an approximation he gives 50 kilowatt-hours per 1000 ton miles. In the winter months about ten per cent has to be added to this for train heating. The second part deals with the consumption of energy for railway traction in Great Britain, giving figures for each electrified line, with the source of supply and the half-hourly maximum demand. In the third part fluctuations of traction load and the ratio of the average to the maximum demand are discussed. Mr. Lydall states that, in general, for a new scheme of electrification, it would not pay a railway to provide its own power. The Southern Railway derives its electricity from three sources, its own power station, a power company and the Central Electricity Board. On the subject of the supply of energy for electric railways, fifteen papers were received by the Conference-four from France, two each from Germany and Switzerland, and one each from the Argentine, Denmark, Japan, Norway, Sweden, Great Britain and the United States.

\section{The Central ; Armstrong Memorial Number}

OLD Centralians, their children and their wives, their servants and even the stranger within their gates, will do well to read the Armstrong Memorial Number of The Central (35, No. 83 ; June 1938) to be reminded in simple, vigorous form of the lifework of a rugged old man whom so many of us were proud to call friend. The photographs of him are excellent and the appreciations of one whose giant mental stature made any attempt at appraising his qualities during his lifetime a graceless task-was he not "H. E. A." ?-are just. Dr. E. F. Armstrong is to be congratulated on his choice of material no less than upon his handling of his father's documents. The result is worthy of the considerable labour that must have gone to the making, and it has the authentic Armstrong ring. The number must have pleased the professor himself-had one been able to take it round to show him. The author's lively wit illumines the section of his autobiography included here. Chemistry was to "H. E. A." a philosophy of life, and he had a biting scorn for those who thought it merely a means of earning a livelihood. He could never recommend us to suffer fools gladly, and he had an eagle eye for folly in scientific research. His (to his friends) familiar advice : "Sack the lot !" was more indicative of his true insight into the problems of this generation than many supposed. One is glad to think that this almost classic phrase has found a place in his memorial number of The Central: the old man would have had it so !

\section{Centenary of Portuguese Medical Schools}

Philatelists and medical historians among others will be interested to know of the recent issue of a stamp of 25 centavos, of which a correspondent has sent us a specimen, on the occasion of the celebration on March 6, 1937, of the foundation of the medical schools of Lisbon and Oporto. Before the establish. ment of these schools, as we learn from a contemporary account (British and Foreign Medical Review, p. 284 ; July 1838), the majority of medical men in Portugal were very ignorant, knowing little of either anatomy or surgery. Many surgeons indeed were in practice who had never studied at any school. These men had not been examined by professors or teachers, but merely by surgeons in any part of the country selected by the chief surgeon of the kingdom. In some cases, no authority of any kind had been given. The value of the medical instruction in the new schools was shown not only by the presence of the most eminent Portuguese physicians and surgeons on the staff but also by the fact that shortly after the foundation of these schools the departure of future doctors for qualification abroad came to an end. Moreover, the improvement in education and the high standard required of candidates before receiving their diploma resulted in a considerable rise in the social status of the medical profession in Portugal.

\section{Bio-Morphosis}

ThE first number of a new journal, Bio-MorphosisInternational Journal of Morphology and Biology of Man and the higher Vertebrates, has recently appeared. Prof. Bluntschli, of Bern, is principal editor, and the publisher is Karger, of Basle and Leipzig. The editorial board includes representatives from Sweden, Poland, China, Hungary, Holland, the United States, etc., and such well-known names as those of Profs. J. P. Hill, G. Levi and E. Fauré-Fremiet. In his general introduction, the editor points out that morphological and physiological researches have for decades been isolated from one another. The journal therefore has the very laudable aim of reconciling and exchanging the ideas of these two ways of biological investigation. Contributions on subjects possessing both morphological and physiological interest are therefore invited. They may be in English or French or German, summaries in the languages not used being provided at the conclusion of the paper. In the first issue, F. Weidenreich discusses the evolution of man in the light of new discoveries about Sinanthropus, Pithecanthropus, etc., coming to the rather surprising conclusion that "the developmental factors of Lamarckian and Darwinian conception are of no importance, the essence of the evolution being an independent progressive differentia- 